\title{
Venoarterial Extracorporeal Membrane Oxygenation is Effective in Severe Aluminum Phosphide Overdose Despite Delayed Presentation
}

\author{
Pradeep Kumar $\mathrm{HG}^{1} \odot$, Madhusudan Kalluraya $\mathrm{A}^{2} \odot$, Jithendra $\mathrm{C}^{3} \odot$, Ashwin Kumar ${ }^{4} \odot$, Sudhindra $\mathrm{P}$ Kanavehalli ${ }^{5} \odot$, Arul $\mathrm{D}$ \\ Furtado $^{6}$, Ravindra Mehta ${ }^{7}$ [0
}

\begin{abstract}
Aluminum phosphide (ALP) is a potentially lethal poison. The mortality rate in ALP overdose is close to $100 \%$. ALP has no specific antidote, and only supportive therapy is possible, with timely extracorporeal support mentioned as a modality. We present a case of severe ALP overdose in a young female with delayed presentation ( $>24$ hours) and multiorgan failure (MOF)/shock successfully managed with veno-arterial extracorporeal membrane oxygenation (VA-ECMO). Unique features of this case include consumption of lethal quantity of ALP (5 g), severe toxicity with MOF, and shock secondary to a delayed presentation, all of which incrementally added to a high mortality. This was managed with the help of VA-ECMO as a last option with a successful outcome. This highlights the fact that late ECMO deployment, despite absorption of a large quantity and MOF/shock/acidosis, can still be salvageable with appropriate management.

Keywords: Aluminum phosphide, ECMO, Multi-organ dysfunction.

Indian Journal of Critical Care Medicine (2021): 10.5005/jp-journals-10071-24041
\end{abstract}

\section{INTRODUCTION}

Aluminum phosphide (ALP) overdose is the most common agricultural pesticide overdose in India. ${ }^{1}$ Human exposure can be accidental or suicidal. ${ }^{2}$ ALP is an extremely lethal poison which releases phosphine upon contact with moisture, particularly in acidic environment. Phosphine acts as cellular toxin and inhibits cytochrome oxidase in mitochondria, and the resultant inability to utilize oxygen leads to lactic acidosis and eventually cell death and multi-organ dysfunction. ALP has no specific antidote, and only supportive therapy is possible, with timely extracorporeal support mentioned as a modality. We present a case of severe ALP overdose in a young female with delayed presentation (>24 hours) and multi-organ failure (MOF)/shock successfully managed with veno-arterial extracorporeal membrane oxygenation (VA-ECMO).

\section{Case Description}

A 29-year-old female presented after consuming 10 tablets $(5 \mathrm{~g})$ of ALP. She was initiated on vasopressors for hypotension, dialyzed for worsening metabolic acidosis, and referred to our center for hemodynamic worsening with persistent metabolic acidosis.

On presentation, she had hypotension requiring three vasopressors. She was conscious and irritable. There was severe lactic acidosis with serum lactate $(9 \mathrm{mmol} / \mathrm{dL})$. Initial echocardiography showed severe left ventricular dysfunction (LVEF $=30-35 \%)$. In view of refractory shock, persistent metabolic acidosis, and imminent collapse, VA-ECMO was proposed. She was intubated and ventilated, and ECMO was initiated within 5 hours of hospital admission. The left femoral artery was cannulated with a $15 \mathrm{Fr}$ proximal cannula and an $8 \mathrm{Fr}$ distal cannula for distal limb perfusion. The right femoral vein was cannulated with $24 \mathrm{Fr}$ venous
1,2,5,7 Department of Pulmonology and Critical Care Medicine, Apollo Speciality Hospital, Bengaluru, Karnataka, India

${ }^{3,4}$ Department of Critical Care Medicine, Apollo Speciality Hospital, Bengaluru, Karnataka, India

${ }^{6}$ Department of Cardiovascular and Thoracic Surgery, Apollo Speciality Hospital, Bengaluru, Karnataka, India

Corresponding Author: Pradeep Kumar HG, Department of Pulmonology and Critical Care Medicine, Apollo Speciality Hospital, Bengaluru, Karnataka, India, Phone: +91 9986013963, e-mail: pradeepkumar.deepu96@gmail.com

How to cite this article: Kumar PHG, Kalluraya MA, Jithendra $C$, Kumar A, Kanavehalli SP, Furtado AD, et al. Venoarterial Extracorporeal Membrane Oxygenation is Effective in Severe Aluminum Phosphide Overdose Despite Delayed Presentation. Indian J Crit Care Med 2021;25(12):1459-1461.

Source of support: Nil

Conflict of interest: None

cannula with tip positioned at the right atrium. After heparinization, VA-ECMO was initiated, and initial ECMO pump flows were set at 3.5 L per minute.

Serial echocardiography showed improvement in LV function, and she was weaned off vasopressor support with resolving lactic acidosis. With clinical improvement, ECMO flows were slowly tapered and ECMO discontinued successfully after 48 hours (Table 1). Her stay in ICU was complicated with acute kidney injury (AKI) (serum creatinine-2.2, EGFR-40 mL/minute), but she did not require renal replacement therapy (RRT). She had thrombocytopenia (nadir-75,000/ $\mu \mathrm{L}$ ) probably related to heparin exposure requiring platelet transfusion, with no bleeding. She was successfully weaned off the ventilator on the third day, transferred to ward on the fifth day and discharged subsequently.

(c) The Author(s). 2021 Open Access This article is distributed under the terms of the Creative Commons Attribution 4.0 International License (https://creativecommons. org/licenses/by-nc/4.0/), which permits unrestricted use, distribution, and non-commercial reproduction in any medium, provided you give appropriate credit to the original author(s) and the source, provide a link to the Creative Commons license, and indicate if changes were made. The Creative Commons Public Domain Dedication waiver (http://creativecommons.org/publicdomain/zero/1.0/) applies to the data made available in this article, unless otherwise stated. 
VA-ECMO Effect in Severe ALP Overdose

Table 1: Trend of various parameters till the patient got discharged

\begin{tabular}{|c|c|c|c|c|}
\hline Parameter & At admission & 12-hours after ECMO initiation & $\begin{array}{c}\text { Post-ECMO/before } \\
\text { extubation }\end{array}$ & At discharge \\
\hline $\mathrm{pH}$ & 7.16 & 7.30 & 7.40 & 7.41 \\
\hline Bicarbonate & $13.5 \mathrm{mmol} / \mathrm{L}$ & $16.7 \mathrm{mmol} / \mathrm{L}$ & $22.8 \mathrm{mmol} / \mathrm{L}$ & $23 \mathrm{mmol} / \mathrm{L}$ \\
\hline Lactate & $9.0 \mathrm{mmol} / \mathrm{L}$ & $10.0 \mathrm{mmol} / \mathrm{L}$ & $1.2 \mathrm{mmol} / \mathrm{L}$ & $0.8 \mathrm{mmol} / \mathrm{L}$ \\
\hline Vasopressor support & $\begin{array}{l}\text { Noradrenaline }-5 \mu \mathrm{g} / \mathrm{kg} / \text { minute } \\
\text { Adrenaline }-2 \mu \mathrm{g} / \mathrm{kg} / \mathrm{minute} \\
\text { Vasopressin-0.04 units/hour }\end{array}$ & $\begin{array}{l}\text { Noradrenaline }-2 \mu \mathrm{g} / \mathrm{kg} / \text { minute } \\
\text { Adrenaline }-1 \mu \mathrm{g} / \mathrm{kg} / \text { minute }\end{array}$ & $\mathrm{Nil}$ & $\mathrm{Nil}$ \\
\hline Serum creatinine & $1.18 \mathrm{mg} / \mathrm{dL}$ & $2.2 \mathrm{mg} / \mathrm{dL}$ & $1.32 \mathrm{mg} / \mathrm{dL}$ & $0.8 \mathrm{mg} / \mathrm{dL}$ \\
\hline Ejection fraction & $30-35 \%$ & $40 \%$ & $50 \%$ & $55 \%$ \\
\hline Sensorium & Conscious, irritable & Conscious & Conscious & Conscious \\
\hline
\end{tabular}

\section{Discussion}

ALP is a potentially lethal poison. The lethal dose described in the literature is $10 \mathrm{mg}$ per $\mathrm{kg}$, and a dose of $0.5-1.0 \mathrm{~g}$ can be fatal. ${ }^{2-4}$ The amount ingested by our patient was significantly above the fatal dose $(5 \mathrm{~g})$.

The mortality rate in ALP overdose is close to $100 \%$ in some studies. ${ }^{5-7}$ The high mortality is due to lack of specific antidote and also due to the lethal action of phosphine which acts as a cellular toxin causing cellular hypoxia. ${ }^{8,9}$ The average time interval between consumption and death reported was 3 hours (range: $1-48$ hours) with $95 \%$ mortality within 24 hours. Cardiovascular involvement is the major issue, ${ }^{9}$ with severe reduction of LV systolic function. ${ }^{13,14}$ Acute deterioration followed by cardiovascular collapse is the commonest clinical presentation, also seen in our case. Various autopsy studies have reported microscopic findings in the form of myocardial congestion with necrosis, vacuolar changes, and infiltration of myocytes by neutrophils and eosinophils. ${ }^{9-12}$ Studies have reported that the cardiac dysfunction starts to improve by the fifth day onward (range 10-14 days). ${ }^{15,16}$ Aggressive cardiovascular support during the acute phase is recommended to prevent end-organ damage due to poor perfusion and halts progression to MOF and death.

Severe ALP toxicity in our patient was evident with several parameters. ${ }^{17-19}$ These included cardiogenic shock, metabolic acidosis ( $\mathrm{pH}<7.2$ ), bicarbonate $<15 \mathrm{mmol}$ per $\mathrm{L}$, Acute Physiology and Chronic Health Evaluation II (APACHE-II) scores, need for mechanical ventilation, and elevated leucocyte count. Mathai et al. reported mortality rates of $73 \%$ in cases with APACHE-II scores of $>8$, and $69.2 \%$ in cases with SAPS-II score in excess of 30 . APACHE-II score was a better predictor of mortality than SAPS-II scores in their study. ${ }^{17}$ The APACHE-II score was 14 , and sequential organ failure assessment score was 7 in our case. The case for VA-ECMO as a last resort was clear with such severe ALP toxicity. The timing of ECMO initiation was however an issue, as success is limited after delayed deployment as discussed below.

In a study by Mohan et al., the average duration from exposure to ECMO initiation in survivors was $8.9 \pm 3.3$ hours. $^{21}$ In our case, there was a significant delay in presentation (29 hours). In another study by Mohan et al., the average duration from admission to ECMO initiation was $3.5 \pm 3.2$ hours. $^{22}$ In our case, admission to ECMO initiation was 5 hours. The mortality rate described in their study was 40 and $33 \%$, respectively. ${ }^{21,22}$ Our patient survived despite two adverse factors - consumption of large doses of ALP and presenting with significant delay ( $>24$ hours).
The major complication observed in patients on ECMO is bleeding. ${ }^{20,23}$ In our patient, bleeding was not an issue despite a drop in platelet count (nadir-75,000/ $\mu \mathrm{L}$ ) secondary to heparinization. A meta-analysis by Cheng et al. showed that the incidence of bleeding in patients with shock on ECMO was $41 \% .{ }^{23}$ The incidence of AKI was $56 \%$ in patients with shock requiring $\mathrm{ECMO}$, and in patients requiring RRT, it was $46 \% .{ }^{23}$ Our patient also had AKI (non-oliguric) and did not require RRT. In terms of technical issues, the incidence of arterial ischemic complications related to arterial cannulation is high. ${ }^{23}$ However, ischemic complications can be reduced significantly with the distal perfusion cannula, which was placed in our patient with no ischemic complications. ${ }^{24}$

Unique features of this case include consumption of higher quantity of $\operatorname{ALP}(5 \mathrm{~g})$, severe toxicity with MOF, and shock secondary to a delayed presentation, all of which incrementally added to a high mortality. This was managed with the help of VA-ECMO as a last option with a successful outcome. This highlights the fact that late ECMO deployment despite absorption of a large quantity and MOF/shock/ acidosis can still be salvageable with appropriate management.

\section{Conclusion}

Aluminum phosphide (ALP) is a highly toxic substance, and its consumption is associated with high mortality. There is no antidote, and various treatment options over the years had little impact on mortality. Our report shows that VA-ECMO can reduce mortality even in patients who consume large doses and with late presentation ( $>24$ hours). Early referral to an ECMO center is important, and VA-ECMO should be considered as salvage therapy in severe ALP overdose despite delayed presentation.

\section{ORCID}

Pradeep Kumar HG @ https://orcid.org/0000-0002-7981-3711

Madhusudan Kalluraya A ๑ https://orcid.org/0000-0003-3111-533X

Jithendra C 이 https://orcid.org/0000-0002-1653-9823

Ashwin Kumar (1) https://orcid.org/0000-0002-6975-5861

Sudhindra P Kanavehalli @ i https://orcid.org/0000-0003-4804-3213

Arul D Furtado @ https://orcid.org/0000-0001-8943-0901

Ravindra Mehta ๑ https://orcid.org/0000-0003-2015-0236

\section{References}

1. Srivastava A, Peshin SS, Kaleekal T, Gupta SK. An epidemiological study of poisoning cases reported to the National Poisons Information 
Centre, All India Institute of Medical Sciences, New Delhi. Hum Exp Toxicol 2005;24(6):279-285. DOI: 10.1191/0960327105ht527oa.

2. Kumar A, Pathak A, Verma A, Kumar S. Accidental inhalational poisoning by multiple pesticides of organophosphorus group in an aged person; an uncommon occurrence. J Forensic Med Toxicol 2012;29(2):78-83 .

3. Wahab A, Zaheer MS, Wahab S, Khan RA. Acute aluminium phosphide poisoning: an update. Hong Kong J Emerg Med 2008;15:152-155. DOI: $10.1177 \% 2 F 102490790801500306$.

4. Sudakin DL. Occupational exposure to aluminium phosphide and phosphine gas? A suspected case report and review of the literature. Hum Exp Toxicol 2005;24(1):27-33. DOI: 10.1191\%2F0960327105ht496oa.

5. Chugh SN, Ram S, Sharma A, Arora BB, Saini AS, Malhotra KC. Adrenocortical involvement in aluminium phosphide poisoning. Indian J Med Res 1989;90:289-294. PMID: 2620956.

6. Chugh SN, Dushyant, Ram S, Arora B, Malhotra KC. Incidence \& outcome of aluminium phosphide poisoning in a hospital study. Indian J Med Res 1991;94:232-235. PMID: 1937606.

7. Wahab A, Rabbani MU, Wahab S, Khan RA. Spontaneous self-ignition in a case of acute aluminium phosphide poisoning. Am J Emerg Med 2009;27(6):752. DOI: 10.1016/j.ajem.2008.09.045.

8. Moghadamnia AA. An update on toxicology of aluminum phosphide. Daru 2012;20(1):25. DOI: 10.1186/2008-2231-20-25.

9. Tripathi SK, Gautam CS, Sharma PL. Clinical pharmacology of aluminium phosphide poisoning. Ind J Pharmacol 1992;24(3):134-137.

10. Jain AK, Nigam M, Garg SD, Dubey BP, Arora A. Aluminium phosphide poisoning autopsy findings. J Indian Academy Forensic Med 2005;27(1):35-39.

11. Arora B, Punia RS, Kalra R, Chugh SN, Arora DR. Histopathological changes in aluminium phosphide poisoning. J Indian Med Assoc 1995;93(10):380-381. PMID: 9053411.

12. Chugh SN, Chugh K, Ram S, Malhotra KC. Electrocardiographic abnormalities in aluminium phosphide poisoning with special reference to its incidence, pathogenesis, mortality and histopathology. J Indian Med Assoc 1991;89(2):32-35. PMID: 2056173.

13. Bogle RG, Theron P, Brooks P, Dargan PI, Redhead J. Aluminium phosphide poisoning. Emerg Med J 2006;23(1):3. DOI: 10.1136/ emj.2004.015941.

14. Bhasin P, Mital HS, Mitra A. An echocardiographic study in aluminium phosphide poisoning. J Assoc Phys India 1991;39:851.
15. Gupta MS, Malik A, Sharma VK. Cardiovascular manifestations in aluminium phosphide poisoning with special reference to echocardiographic changes. J Assoc Phys India 1995;43(11):773-774, 779-780. PMID: 8773039.

16. Chauhan M, Dewan S, Attawar S, Kamat S, Kumar V, Manhas V, et al. Successful treatment of cardiotoxicity of aluminium phosphide poisoning with extracorporeal membrane oxygenation (ECMO): a case report. J Pharmacol Clin Toxicol 2015;3(4):1056.

17. Mathai $A, B$ hanu MS. Acute aluminium phosphide poisoning: can we predict mortality? Indian J Anaesth 2010;54(4):302-307. DOI: 10.4103/0019-5049.68372.

18. Hosseinian A, Pakravan N, Rafiei A, Feyzbakhsh SM. Aluminum phosphide poisoning known as rice tablet: a common toxicity in North Iran. Indian J Med Sci 2011;65(4):143-150. DOI: 10.4103/00195359.104777 .

19. Shadnia S, Mehrpour O, Soltaninejad K. A simplified acute physiology score in the prediction of acute aluminum phosphide poisoning outcome. Indian J Med Sci 2010;64(12):532-539. DOI: 10.4103/00195359.75928.

20. Paden ML, Conrad SA, Rycus PT, Thiagarajan RR, ELSO Registry. Extracorporeal Life Support Organization registry report 2012. ASAIO J 2013;59(3):202-210. DOI: 10.1097/MAT.0b013e3182904a52.

21. Mohan B, Gupta V, Ralhan S, Gupta D, Puri S, Mahajan R, et al. Impact of extra-corporeal membrane oxygenation on outcome of aluminium phosphide poisoning complicated with myocardial dysfunction. Clin Toxicol 2019;57(11):1095-1102. DOI: 10.1080/ 15563650.2019.1584297.

22. Mohan B, Singh B, Gupta V, Ralhan S, Gupta D, Puri S, et al. Outcome of patients supported by extracorporeal membrane oxygenation for aluminum phosphide poisoning: an observational study. Indian Heart J 2016;68(3):295-301. DOI: 10.1016/j.ihj.2016.03.024.

23. Cheng R, Hachamovitch R, Kittleson M, Patel J, Arabia F, Moriguchi J, et al. Complications of extracorporeal membrane oxygenation for treatment of cardiogenic shock and cardiac arrest: a meta-analysis of 1866 adult patients. Ann Thorac Surg 2014;97(2):610-616. DOI: 10.1016/j.athoracsur.2013.09.008.

24. Jackson KW, Timpa J, Mcllwain RB, O'Meara C, Kirklin JK, Borasino S, et al. Side-arm grafts for femoral extracorporeal membrane oxygenation cannulation. Ann Thorac Surg 2012;94(5):e111-e112. DOI: 10.1016/j.athoracsur.2012.05.064. 